\title{
Be a Man, do not Cry like a Woman: Analyzing Gender Dynamics in Pakistan
}

\author{
Abdul Razaque Channa*1-2 \& Tayyaba Batool Tahir ${ }^{3}$
}

1. The Lakshmi Mittal \& Family, South Asia Institute, Harvard University, Cambridge, United States.

2. Department of Anthropology and Archaeology, University of Sindh, Jamshoro, Pakistan.

3. Institute of Social and Cultural Studies, Bahauddin Zakariya University, Multan, Pakistan.

\begin{abstract}
Contrary to the view that gender is fluid, as concurred by several social scientists, in traditional Pakistani understanding, gender is seen in fixed binaries, i.e., either you are a man or a woman. The third category is known as the third gender in Pakistan. It is interesting to note that although gender is seen as fixed in Pakistani cultures, in informal discussions, varied shades of gender are highlighted by informants based on gender performativity. By drawing on the postmodern feminist theory of gender performativity, this paper does a discourse analysis of informant's views about gender construction and dynamics in rural Sindh. Ethnographic fieldnotes have been used as primary data to analyze gender nuances implicit in Pakistani men's informal discourse. This paper argues that contrary to unchanging gender identities as endorsed by Pakistan society's patriarchal structure, men dismiss these fixed identities during an informal discussion. Instead, they shuffle gender identities by branding men and women as feminine men and masculine women, respectively, based on their gender performativity. We conclude that irrespective of physical outlook, the power lies in hegemonic forms of agency. Gender relationships and gender performance shape the sexual and gender identity of subjects.
\end{abstract}

Keywords: Gender, Masculinity, Femininity, Gender \& Discourse, Gender Performance, Gender Performativity, Identity, Gender Identity.

\section{Introduction}

This paper explores the ways individuals present gender relations in unconventional ways and how the undoing of gender exists even in a gendered society like Pakistan, where gender norms and values are rigidly defined and practiced strictly (Hussain et al., 2015). Generally, gender is associated with a man or a woman. The third category of gender comprises unisex, transgender, eunuchs, transvestites, in-betweens; all these categories are put under one term of the third gender (Hijra in the Urdu language and Khadro in the Sindhi language) in Pakistan. Moreover, the sex is referred to as a male or a female. However, social scientists, including anthropologists, define gender as the social construction, whereas sex is explained as biological composition. Scholarship produced in Pakistan on gender often limits gender between man and woman and continually does not expand their intellectual lens to see gender beyond dualism (McDonald, 2013; Ullah \& Skelton, 2013). This paper attempts to offer an analysis based on ethnographic field notes to understand the changing dynamics of gender, which go beyond the binary opposition. The paper argues that gender nuances in a country like Pakistan are complex to understand due to socio-cultural and politico-religious subtleties. Still, there is some space 
to see gender beyond binary opposition if the critical feminist postmodern theoretical scholarship is applied. There is some scope because gender conceptualization has changed over time \& space. There is evidence in the quotidian discourse and discursive practices that Pakistanis use to contest the established gendered norms and behaviours.

Ethnographic data provides an insight into the conceptualization of gender and how it shifts gender identity in certain pockets of society. The ethnographic examples are given below, which were not the dominant mode of communication. However, these discourses specify an alternative to the prevailing norms of gender in Sindhi society. Participants of this research offer glimpses to the hegemonic forms of masculinities and emphasized forms of femininities. Inhabitants of Shahdadkot unconventionally conceptualized men and women and presented women as powerful to men and men as inferior and subservient to females. This paper deconstructs the myth of powerful men and disempowered women because there were certain examples within the Sindhi society where men admitted women's strength and dominance. The image of powerful women is constructed on man's established notion of masculinity because powerful women were assertive, dominant, fearless, rational and their behaviour was uncompromising.

\section{Contextualizing Gender dynamics in Pakistan}

Gender dynamics is a complex phenomenon in Pakistani society influenced by varied factors such as: province/area, social class, educational background, family background and religious affiliation. It should be highlighted that Pakistan is a dominant male society where several players of hegemonic masculinities obstruct women's rights. Over the past few decades, Pakistani women's rights activists, social workers, and politicians have worked hard to improve women's situation in Pakistan. The latest Bills regarding women's protection in Pakistan are: Protection against harassment of women at the workplace act (2010), the Acid Control and Acid Crime Prevention bill (2010) and the Prevention of anti-women Practices (2008). As such, women in Pakistan have been given some legal protection. These bills reflect government and parliamentarians' commitment to address gender-based violence, gender-based stereotypes, and women's role in a healthy and developed society. However, there are issues to implement these laws and ensure that women are safe and enjoy a just and equal society member. Butt $e t$ al. (2020) argue that 'at least a dozen laws have been promulgated to safeguard women's rights but no avail.'

In Pakistan, few women receive a chance to pursue higher education and from these few, even a smaller number pursue a career. Previously, some educated women would prefer not to work after getting married. However, recently, due to the changing socio-economic circumstances, many married, educated women have joined the mainstream workforce to help meet their families' expenditures. In fact, some women have become more career-driven and pursue their jobs out of interest in their profession. Despite Pakistani women's increasing contribution to the mainstream workforce, it is difficult to deny the double-standards that most of the Pakistani people have against women, especially regarding working women. Many Pakistani men see empowered Pakistani women as westernized and a threat to their masculine identity; hence they create multiple-barriers for women's career advancement (Ahmad et al., 2020; Daraz et al, 2018; Shah et al., 2020). Traditionally, women's image is associated and confined to the home. Her role is seen as a mother, sister, and housewife. Since Pakistan's social structure is changing due to female higher education, women's rights awareness, women's access to public spaces and opportunities, there are many women who are leading in every sector, including 
government, politics, sports, bureaucracy, business, and media. Women are empowered due to their struggle; however, there is still a long way for a gender just society.

Some characters tend to digress from stereotypical Pakistani gender norms like 'Begum Nawazish Ali (Walsh, 2006) or Masi Moran (KTN Entertainment, 2021)' where men perform as female characters in TV shows and YouTube channels. They have thousands of followers on their digital accounts. There are men and women; literate and non-literate; inhabitants of the rural area and urban area and young and old. These characteristics are very popular. It is also common in Pakistan where girls perform male roles in the school/college and university tableaus and theatres. Such positions are also performed in neighbourhoods across Sindh. Zulfikar Ali Bhutto's recent art pursuit, especially the drag dance on 'Disco Deewany' and his interview as part of 'The Turmeric Project' (The Turmeric Project, June 15, 2017) has deconstructed the idea of the powerful man. His dance and interview were widely debated globally, particularly in Pakistani society, due to his appearance and approach to understanding gender. Many people appreciated him, whereas many were not expecting him to perform a drag dance or challenge the idea of masculinity. He disregarded the notion that power exists between two sexes, i.e., man and woman and that the man is always powerful. His conceptualization of body is beyond man and woman binary opposition. There are queers and lesbians, gays, bisexuals, intersexual, and transgender (LGBIT). He argues that 'masculinity is softness, it can be effeminate' and 'It can be gentle and identities are constructed through violence, conflict and war (The Turmeric Project, June 15, 2017).

\section{Theoretical Framework}

'One is not born, but rather becomes a woman.' The French feminist, Simone-de-Beauvoir, offers this statement in her most celebrated and widely read book, The Second Sex (DeBeauvoir, 2010). The book provides significant insights into sex and gender, highlighting how women might be perceived in certain situations. It provides a historically vivid account of women's lives and how the gender difference operates in any society. While her book offers a detailed account of women's oppression and how men control and characterize women, it also deals with the myths and established gender theories of her times. The book's strength permeates a new discourse among the feminists and intellectuals interested in gender studies and sexualities.

The discourse employed in the construction of gender and sexuality suggests that being a woman or a man is not just a matter of biological composition. Instead, there is a history embedded within the social construction of a binary 'reality' characterizing, shaping, and ultimately restricting men and women's identities differently. 'It is the culture rather than a fact of nature' argued by Sherry B. Ortner, an American anthropologist, in her famous article, Is Female to Male as Nature is to Culture? (Ortner, 1972). This cultural construction of stereotyped sexuality is contingent and fluid, which allows for the re-making of identity. Cultural repertoire plays a significant role in constructing a powerful man's identity or subjugating a submissive woman. Societal discourse establishes norms, values, stereotypes, and myths related to men and women. These cultural repertoires and societal discourse change with time and space so are the principles and standards of any society. Briefly, gender and sexuality are not static or fixed but a subtle and flexible form of identity. The identity of any person is always in perpetual flux. Today, a woman may not identify with the woman she might become tomorrow, and obviously, she may not be the same tomorrow as the woman she is today. The 'powerful' man may not necessarily remain dominant in the future as society's idea 
of what constitutes 'power' and those legitimated to possess may change.

Can a man become feminine and a woman masculine? R.W. Connell, an Australian sociologist, introduces 'Hegemonic Masculinities' and 'Emphasized Femininities' in her book Gender and Power (Connell, 1987). She goes beyond the ideas of gender identity, or gender is just about man and woman only. The spectrum is possibly infinite, and sex focuses on the hegemonic traits that shape multiple masculinities irrespective of physiology. Connell argues it becomes instead a matter of the gender and power relationships that shape the 'social intelligence' a person acquires to understand how to perform, act, learn, react, and sometimes survive in a vast array of social situations. Gender and power relationships are significant because normative characteristics of men are conceptualized to subjugate women in society. These idealized, normalized, and standardized hegemonic masculinities become the dominant force to subjugate an individual's agency.

Masculinity and femininity do not necessarily reflect an individual's ontological manufacturing, but it is a composition of characteristics that society assigns, delineates, and sets as norms. As Judith Butler, an American gender theorist, explains in her book Gender Trouble: Feminism and identity subversion (Butler, 2011). Gender 'characters' are performed, taught, socialized, incorporated, inculcated, and practiced becoming the primary means for gender construction. These socially constructed norms become the standard, approved by most determining the default components for defining anyone's sexuality and gendered identity (Atencio \& Koca, 2011; Butler, 1988). Society makes a man an acceptable man in any particular society; likewise, a woman is imagined in the historical contextualization of feminine roles. Since society is not still and it does not remain the same, so is the case with the image of man and woman's body and their characteristic performance. For example, dance is associated with women. She is expected to keep long hair. She is anticipated to be emotional, fearful, subservient, and weak. However, there are many examples in the society where men dance, keep long hair, and do not hesitate to show their emotions, fear, and help. It is not just body, anatomy or physical substance that is powerful, but the power lies in the presentation, performance, and characteristics. These gender characteristics are changing so is the gender performance in society. The power lies in the discourse and discursive practices of hegemonic masculinity. There are two critical terms i.e., discourse and power, which we will frequently use for this study to understand the gender dynamics in Sindhi society. The post-modernist Foucauldian approach is implied while analyzing the particular statements/sayings of our research participants.

We use discourse and power as critical theoretical concepts to understand changing gender subtleties in Pakistan's Sindh. Although the term discourse has always found a prominent place in Foucault's various writings, it has almost denoted the same purpose. That is, by using the term, he has either referred to the reports, documents, decisions, or to the acts which have either constructed or resisted specific subjectivity/identity in a particular field (Foucault, 1980, 1982; Foucault et al., 1997; Rabinow, 1984). For instance, Foucault has discussed the role of discourses concerning how discourses have produced a sexual subject in his History of Sexuality in the field of religion and ethics (Foucault, 1978, 2012; Foucault et al., 1997). He has discussed how discourses have produced a criminal and delinquent identity in Discipline and Punishment (Foucault, 1977) in the field of law and sociology. He has argued how discourses have subjected an individual in his Order of the Things ( Foucault, 1970; Foucault, 1972) in the field of knowledge. Thus, according to Foucault, discourses seem to implicitly guide and transform mechanisms working on social actors' perception of reality. We take 
discourse as a way of communication that has cultural meaning and symbolizes message. Discourse having culturally relevant purpose and the embodiment of statement, we argue, hold power in social relationships of human society (Blommaert, 2005; Clyne \& Clyne, 1996). For instances, when a man says 'مرد ثئ 'Be a man' or 'هوَّ بجلي ثني 'She is like power/electricity.' These sentences are not mere statements, but they embody the cultural meaning of gender relationship and gender power.

The second concept that we will be using for this study is Power. Unlike the impression that power is horrible and sordid and always in the hands of a few people, Foucault finds power positive and omnipresent. He sees power not only in the domain conventionally associated with the concept but as pervasive in all institutional and personal relations and verbal and non-verbal transactions. Resultantly, power appears not to be a characteristic of a specific field of society but synonymous with power relations in daily social life, mainly constructed and perpetuated through discourses (Cheong \& Miller, 2000; DuBois, 1991; Foucault, 1980; Hall, 2001). Like him, we also believe that power is everywhere. Everyone uses power in different contexts. Power is not static but fluid. Taking the omnipresence of power, it is affirmative and manufacturing nature, and its attachment with the discourses of specific fields into account, such as Sindhi society and gender discourse.

\section{Research Methodology}

Qualitative research data is used as the primary research methods for this study by conducting extensive ethnographic fieldwork in Shahdadkot, a rural town of District Qamber-Shahdadkot of Sindh Province of Pakistan. The town is located on the border area of Balochistan province hence the strict gender norms and values persist. Still, there are feudal lords in the town who have greater control of the modes and means of production and enjoy de-facto authority over ordinary folks. After spending months, the researchers had established a respectable understanding with the community members and had a greater understanding with the key informants. Once familiarized with the local context and cultural values, researchers had an opportunity to spend long hours discussing various topics with respondents. They knew us well due to our networking with the schoolteachers and administration where we were conducting the fieldwork. Respondents - men and women - were open to sharing jokes, sayings, anecdotes, and anything that interested them since we had no restriction strictly on the topic. Moreover, time duration was not defined to start and end the discussion. A wide range of ethnographic research methods and data collection protocols such as participant observation, interviews, focus group discussions and surveys were used to collect data for this research.

During informal discussions, it has been observed from the data that various interesting social issues, academic themes, and cultural repertoires regarding gender, masculinity, and femininity-related discourse emerged. Purposive sampling method was used to reach out to only respondents interested in openly discussing and discussing the different aspects of their gender. There were five individuals whom researchers spent extensively long hours talking and discussing gender relationships. To respect privacy, their identities are not disclosed in any way except the discourse. The researchers took their consent to use their discussion. Respondents were open, and they even shared things that otherwise were not acceptable. They joked and freely challenged their manliness; in-fact, this was considered shameful and unconventional in a formal talk in a traditional Sindhi Society. This free mode non-time bound discussions allowed us to explore the nuances and dynamics of the Sindhi Culture and how the inhabitants see men and women relations in Shahdadkot. The daily gender related repertoire 
influenced the authors of this article to document, conceptualize the fieldnotes and theorize the changing gender identity of Sindhi society.

\section{Ethnographic Data: Discussion and Analysis}

The following discursive repertoire is found in Pakistan's Sindh Province. It is used daily and found widely in all pockets of society. Interestingly, such subtle and discreet discourse - 'he' is represented with 'she' and 'feminine behaviour' symbolizes 'manliness' - is shared and exchanged in a friendly manner through jokes, reference points, and sometimes insulting someone to win the argument of friends. In the theorists mentioned above, such discourse offers quite interesting insights into the construction of gender and sexuality in Sindhi culture and how it is used to promote or subjugate individuals and groups. Apart from the alternative representation of gender, the following discourse also deconstructs the myth of powerful man and subservient woman especially in a patriarchal society where gender norms are harsh. It decolonizes the normalized gendered bodies of males and females in a male-dominated structure of society and breaks the established gender categories of dualism and binary.

Below are some examples of how gender is used to curtail or demand certain men and women's behaviours in Sindh, Pakistan.

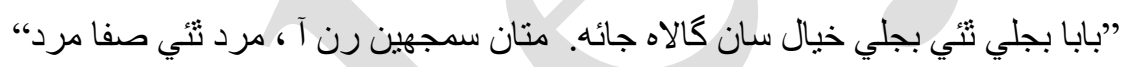

"Baba bijli thai bijli, khiyal sa galahe jae. Mata samjhae run aa, murd thai safa murd."

Author's translation: "Dear mate, be careful while you talk to her. She is like electricity, a power. Don't you think she is merely a woman? She is a man; I mean man!"

Or;

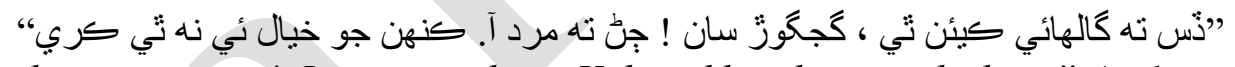

"Dis ta galahy kean thi, gujgoar sa! Jur ta murd aa. Keh jo khiyal ee na thi kary" Authors Translation: "Look at her the way she talks, so fiercely, as if she is the man. She does not care anyone."

Generally, Sindhi society does not encourage women to talk loudly because it is expected that respectable women should stay at home and her voice should not cross the four walls of the house. Likewise, women are categorized 'Shareef (respectable)' if they are gentle in their behaviour and their tone and volume is low to the level that it is heard by family members and does not cross the boundary wall. Usually, they are not assertive and expressive about their demands. Contrary to this, it is normal that men should talk. They are expected to talk as if a lion roar. This is the norm in many societies where women are expected to remain at home and be obedient to their father, husband, brother, and other family members. Women are expected to be passive and subservient. Going against societal gender-related values brings women to the limelight because she challenges society's patriarchal ethos and becomes the symbol of forceful women whom even men become cautious. Her attributes of being assertive and expressive reflect the hegemonic notion of masculinity. She is regarded as not a woman but a man; hence, she should be taken seriously and carefully. Her gender identity is constructed based on her gender performance which goes beyond her anatomical structure due to her agency and power.

Discourse like the respondent's remarks such as 'she is like electricity' creates powerful subjects which offer an opportunity to understand women in an unconventional way: that 
women have the power to destroy, kill and endanger someone. She is like fire which can engulf and destroy anything and anyone. Women are seen as powerful. This shifting gender identity is not appreciated by all in Sindh, and all women and men do not say such things all the time because such subtle discourse threatens gender norms. However, there are examples in society's pockets that provide insight into conceptualizing hegemonic masculinities where men and women perform their gender roles quite contrary to the idealized gender roles.

$$
\begin{aligned}
& \text { ازّي يار كنهن جي تُا جالهُ كريو ؟ اهيو ته مردن جو كم آ جو ميدان نه جذّي با قي هي ته عورت آ، كهمي به رنن } \\
& \text { و انكري كَالهائي به رن ون و انكر }
\end{aligned}
$$

"Ary Yar keh ji tha galh karyo? Eho ta mardan jo kum aa jo maidan na chady baki he ta orat aa, ghumy be runun wangar aie galahy be unhun wangar."

Author's translation: "Dear friends, to whom you are talking about? This is a man's task to not give up in any situation. He is a she, a woman. His gate and his speech replicate them."

Many societies, including Sindhi, construct manliness with certain characters such as 'brave,' 'fighter,' 'protector,' 'tough' and 'someone who never gives up' in any situation. The man is anticipated to use masculine power among his peer members during any conflict, fight, or argument. Contrary to these notions of 'bravery' and 'fighter,' a man is associated as a female who cannot live up to the male-dominated society's demands. His failure to perform required gender roles challenges his gender identity. Hence, his actions and behaviour are constructed as feminine, reflected in a respondent's above remark. The discourses and the discursive practices like the way you walk 'gate' and the way you speak 'speech' are seen as essential traits in society to judge someone as man and woman. Society labels men who fail to walk, talk, and behave like a man as envisioned by societies' male-dominant structures (Rind et al., 2018). Such men with feminine 'gate' and 'speech' face challenges because neither men nor women accept them as their members. They face various stigmas and stereotypes. Sometimes, they live a stressful life and face every day dislike and hatred. In this liminal period of being a man or a woman, powerful men outcast them from mainstream society just because they do not fit into the standards of the patriarchal structure of the society.

"Ary Murd thi, runun wangar tho roee payo."

”ازّي مرد ثي ، رنن و انكر ثُّ روئين“،

Authors Translation: "Hey, be a man! Don't cry like women."

Generally, men are not expected to cry or weep in many societies which have patriarchal societal structure. Likewise, in Sindh, men should not cry or weep; if they do, they are labelled as 'sissy' or feminine because society has established norms for men and women. Men are brave, and they are suitable to control their emotions: this is promulgated in society by the majority of the people. They do not show their weakness in public. However, contrary to the norm associated with men's masculinity, women cry and weep. They are not seen as men. It is for women to weep because they are sensitive, weak, and are unable to control their emotions. Women are expected to cry and weep because this is what women do when they are in difficult situations. This is the norm. Norms related to 'weeping or crying' construct the gender identity of men and women differently, and those who do not fulfil the expectations of society are implied as unfit and not worthy of being respectable members of the community. 'cry' and 'weeping' is normalized in society so doing contrary to this norm is like going against the societal gender related expectations set for men and women. 
The ethnographic data given in the above examples highlights a few points. Firstly, the characteristics of an ideal man or woman in Pakistani culture, which leads to ideal cultural gender norms. Secondly, the significance of gender performativity, i.e., irrespective of one's gender identity, if one does not act in accordance to expected gender norms of the society, he/she is put in an alternative gender category. The ideal gender norms for a man in Pakistani society is to be dominant, leader and protector, therefore, men are expected to be tough (Sanauddin, 2015). Whereas, women should be submissive, quiet, and emotional, therefore, women are expected to be kind and caring. Based on gender performativity, if a man is not tough, he is mocked for acting like a woman and vice versa. It is derogatory for men to be categorized in a different gender category (Karsten, 2003). It is a matter of humiliation for a man to be called girl-like or sissy, since, woman is a weak gender, and it challenges men's power and dominance in society. Interestingly, empowered women do not feel shame to be called like men based on their strong leadership or aggressive behaviour largely because it is inculcated in Pakistani gender system that being a man or to be called like a man is a privilege. It has been observed that often fathers call their daughters, who bear the burden of their family, as sons by using phrases توي ته منهجو بث آهي (you are my son). On the contrary, it has not been observed that a father says to his son that you are a daughter to me, rather, it is considered shameful and disgraceful. Shifting gender identities in Pakistan have nuances of privilege and shame. It is a matter of privilege to be a man and act like a man if you are a woman. Whereas, it is a matter of embarrassment to be a woman and act like a woman if you are a man. These understandings of gender fluidity highlight gender politics at play in Pakistani culture.

Based on the ethnographic examples and observations during the fieldwork, this paper argues that subtle and discreet discourses create subjects. Since power is not held by men only, but it can be used by women as well, so the power dynamics change when it comes to gender relations. Gender and power are fluid and shift so quickly in particular situations that various forms of hegemonic masculinities come into being while performing gender while using his/her agency. Similarly, Societal discourse shapes one's gender identity and expression of their sexuality. Society refers to a man who is not 'macho' by invoking derogatory and contemptible words such as 'sissy,' 'flamer,' 'queer,' 'homo,' 'poofter,' 'queen' and 'fag;' while referring to their sexual behaviour as 'unnatural,' 'abnormal,' 'disgusting,' or 'faulty by default.' Considering a woman who is bold and not intimidated by men, who might possess good leadership skills, and can manage a hectic work and home balance and her subordinates, is certainly regarded by some as a woman having a type of 'masculine' power. Likewise, anyone in society who is aggressive, proactive, physically strong, bold, and right (some might argue bad) at managing his feelings is called a 'man.' Contrary to this, a 'woman' is associated with the characteristics such as being fearful, sentimental, irrational, physically weak and prone to tittle-tattling. These concepts reflect the power of discourses and how various subjects use them to subjugate one person over the other. Again, it is not always the man or woman who holds power, but it is the hegemonic form of masculinity where power is seen. Hegemonic forms of masculinity are performed in society by men and women, as seen in the above example.

\section{Conclusion}

These examples and ethnographic accounts presented above suggest that there is an alternative form of gender identity in a Sindhi society. There are men who behave like women and there are women who behave like men. Also, all women and men do not behave like all other women and men. Those who do not meet the societal expectation of 'being women or being men,' often, people stereotype them and make fun of them due to their gender 
performance/expression. Despite the typecast, these women and men operate their agency unequivocally and live their lives. Sometimes, people appreciate them and accept them, otherwise, often they are termed as 'abnormal' and socially unfit. Although Pakistani society is male dominated where patriarchal structure empowers men and allows them to subjugate women. However, ethnographic examples deconstruct the normalized myth of powerful men because many women overtake powerful positions in society. The ethnographic data validates that power is everywhere and power can be used by anyone: there are many women who are dominating, and their assertiveness overtakes the established gender myths. These women are fiercely uncompromising who go a step ahead than their male counterparts. Due to their alternative form of gender performance, the men exemplify them as if these women are men and have 'electricity' and 'fire' to undo anything.

We conclude that irrespective of physical outlook, the power lies in hegemonic forms of agency. Gender relationships and societal discourse and discursive forces shape the sexual and gender identity of subjects. Since gender is socially constructed hence it is dynamic and changes over time. It is not just the physical entity of a person but the agency through which a person behaves and performs his/her gender in a society. Gender performance displays women's subtle power like men and men acting like women, which resultantly exposes shifting gender identity in a complex social structure like Sindhi society. Though contrary to the normative standards practiced by the majority, in a country like Pakistan, the evidence is endorsing the masculine woman (hegemonic masculinities) and feminine man (emphasized femininities) (Connell, 1987; Connell \& Connell, 2005). Perhaps, there is scope to broaden the discourse beyond the binary construction in Pakistan. There is also a need for more research on the topic to comprehend gender dynamics and shifting gender identity in Pakistan.

\section{References}

Ahmad, A., Hafeez, M. R., \& Shahbaz, M. (2020). “Sell-outs, fatsos or whores?" representation of politically active Pakistani women on social media. Pakistan Social Sciences Review, 4(1), 40-50. https://pssr.org.pk/issues/v4/1/sell-outs-fatsos-or-whoresrepresentation-of-politically-active-pakistani-women-on-social-media.pdf

Atencio, M., \& Koca, C. (2011). Gendered communities of practice and the construction of masculinities in Turkish physical education. Gender and Education, 23(1), 59-72. https://doi.org/10.1080/09540250903519444

Blommaert, J. (2005). Discourse: a critical introduction. Cambridge University.

Butler, J. (1988). Performative acts and gender constitution: an essay in phenomenology and feminist theory. Theatre Journal, 40(4), 519-531. https://doi.org/10.2307/3207893

Butler, J. (2011). Gender trouble: feminism and the subversion of identity. Routledge.

Butt, B. I., Ashiq, U., \& Abbas, N. (2020). Pro-women laws and government masquerading: a description of pre-independence and post-independence women legislative framework in Pakistan. Review of Education, Administration \& LAW, 3(3), 395-401. https://doi.org/10.47067/real.v3i3.84

Cheong, S. M., \& Miller, M. L. (2000). Power and tourism: a Foucauldian observation. Annals of Tourism Research, 27(2), 371-390. https://oi.org/10.1016/S0160-7383(99)00065$\underline{1}$

Clyne, M., \& Clyne, M. G. (1996). Inter-cultural communication at work: cultural values in discourse. Cambridge University.

Connell, R. (1987). Gender and power. Polity Press. 
Connell, R. W., \& Connell, R. (2005). Masculinities. University of California.

Daraz, U., Ahmad, A., \& Bilal, M. (2018). Gender inequality in education: an analysis of sociocultural factors and impacts on the economic development of Malakand. Liberal Arts \& Social Sciences International Journal (LASSIJ), 2(2), 50-58.

De-Beauvoir, S. (2010). The second sex. Knopf. https://www.uberty.org/wpcontent/uploads/2015/09/1949 simone-de-beauvoir-the-second-sex.pdf

DuBois, M. (1991). The governance of the third world: a Foucauldian perspective on power relations in development. Alternatives, 16(1), 1-30. https://www.jstor.org/stable/40644700?seq $=1$

Foucault, M. (1970). The order of things: an archaeology of the human sciences. Translated by Les Mots et al. Vintage Books. https://monoskop.org/images/a/a2/Foucault_Michel_The_Order_of_Things_1994.p $\underline{\mathrm{df}}$

Foucault, M. (1972). The archaeology of knowledge and the discourse on language. Translated by A. M. Sheridan Smith. Pantheon Books. https://monoskop.org/images/9/90/Foucault_Michel_Archaeology_of_Knowledge.p $\underline{\mathrm{df}}$

Foucault, M. (1977). Discipline and punish: the birth of the prison (Vol. 227). Translated by Alen Sheridan. Vintage Books. https://monoskop.org/images/4/43/Foucault_Michel_Discipline_and_Punish_The_B irth_of the_Prison_1977_1995.pdf

Foucault, M. (1978). The history of sexuality: an introduction (Vol. 1). Translated by R. Hurley. Pantheon Books. https://suplaney.files.wordpress.com/2010/09/foucault-the-historyof-sexuality-volume-1.pdf

Foucault, M. (1980). Power/knowledge: selected interviews and other writings, 1972-1977. Vintage Books.

Foucault, M. (1982). The subject and power. Critical inquiry, 8(4). 777-795. https://doi.org/10.1086/448181

Foucault, M. (2012). The history of sexuality: the use of pleasure (Vol. 2). Translated by Robert Hurley. Vintage Books. https://monoskop.org/images/a/a3/Foucault_Michel_The_History_of_Sexuality_2 The Use_of_Pleasure.pdf

Foucault, M. (1997). Ethics, subjectivity, and truth: the essential works of Michel Foucault 1954-1984. Edited by Paul Rabinow. Translated by Robert Hurley et al, (Vol. 1). https://monoskop.org/images/0/00/Foucault_Michel_Ethics_Subjectivity_and_Truth . $\mathrm{pdf}$

Hall, S. (2001). Foucault: power, knowledge, and discourse. In M. Wetherell, S. Taylor, \& S. Yates (Eds.), Discourse, theory, and practice (pp. 72-81). Sage.

Hussain, M., Naz, A., Khan, W., Daraz, U., \& Khan, Q. (2015). Gender stereotyping in family: an institutionalized and normative mechanism in Pakhtun society of Pakistan. SAGE Open, 5(3), 1-11. https://doi.org/10.1177/2158244015595258

Karsten, L. (2003). Children's use of public space: the gendered world of the playground. Childhood, 10(4), 457-473. https://doi.org/10.1177/0907568203104005

KTN Entertainment. (2021, 22-01/2021). Masi Moran online. https://www.youtube.com/watch?v=SUJPnWCApGs

McDonald, S. (2013). Boys play cricket, girls play house: examining the gender binary in Pakistani public schools. Sustainable Development Policy Institute. https://books.google.com.au/books?id=_AgYjwEACAAJ 
Ortner, S. B. (1972). Is female to male as nature is to culture? Feminist Studies, 1(2), 5-31. https://doi.org/10.2307/3177638

Rabinow, P. (1984). The Foucault reader. Pantheon Books. https://monoskop.org/images/f/f6/Rabinow_Paul_ed_The_Foucault_Reader_1984.p $\underline{\mathrm{df}}$

Rind, U. K., Shahriar, A., \& Sangi, M. K. (2018). Gender stereotype and gender-based socialisation: an early age development of habitus and its transformation in Bapsi Sidhwa's Ice Candy Man and Water. The Women-Annual Research Journal of Gender Studies, 10(10), 115-131. https://sujo-old.usindh.edu.pk/index.php/THEWOMEN/article/view/4465

Sanauddin, N. (2015). Proverbs and patriarchy: analysis of linguistic sexism and gender relations among the Pashtuns of Pakistan. University of Glasgow.

Shah, S., Bashir, M. S., \& Amin, M. (2020). Career progression of women academics in Pakistani Universities: enablers and barriers. Sir Syed Journal of Education Social Research, 3(3), 11-21. https://doi.org/10.36902/sjesr-vol3-iss3-2020(11-21)

The Turmeric Project. (June 15, 2017). Zulfikar Ali Bhutto. https://www.youtube.com/watch?v=bc8VtrHA8QE\&feature=emb_imp_woyt

Ullah, H., \& Skelton, C. (2013). Gender representation in the public sector schools textbooks $\begin{array}{lllll}\text { of Pakistan. } & \text { Educational } & \text { Studies, } & 39(2), & 183-194 .\end{array}$ https://doi.org/10.1080/03055698.2012.702892

Walsh, D. (2006, 01-14-2012). Pakistan's late-night, cross-dressing TV star. SFGATE. https://www.sfgate.com/news/article/Pakistan-s-late-night-cross-dressing-TV-star2535184.php 